\title{
The future of food - Scenarios and the effect on natural resource use in agriculture in 2050
}

\author{
I.Y.R. Odegard *, E. van der Voet \\ Institute of Environmental Sciences (CML), Industrial Ecology Leiden University, P.O. Box 9518, 2300 RA Leiden, The Netherlands
}

\section{A R T I C L E I N F O}

\section{Article history:}

Received 10 April 2013

Received in revised form 31 August 2013

Accepted 10 October 2013

Available online 23 November 2013

\section{Keywords: \\ Food \\ Scenarios \\ Land \\ Water \\ Fertilizer \\ Agriculture \\ Global}

\begin{abstract}
A B S T R A C T
Do we have the natural resource base to feed future populations? This study gives a quantification of global land use, water use and fertilizer use for the year 2050, for a complete diet and four different futures. Agriculture will need to develop substantially to feed future populations. It is shown that there is a negative correlation between fertilizer use and land use, which makes the necessity of incorporating both in such assessments clear. Water use increases relative to total production and this is going to be a problem unless drastic measures are taken. The high wastage and high consumption of animal products in the developed regions are major contributors to the total global demand. Developing countries' aspirations to such practices are a major factor in increases in diet demand, as are population increases in those regions. In creating a more sustainable food system, a one-solution approach will not do and solutions should combine supply-side and demand-side options. Demand-side solutions should target wastage and animal product consumption. On the supply side, technological development and better feeding efficiency will increase yields. Feeding the future global population, which is necessary to increase living standards worldwide, will require a concerted effort.
\end{abstract}

(c) 2013 Elsevier B.V. All rights reserved.

\section{Introduction}

Resource use and food are popular topics in the current sustainability debate. Presently, a billion people are undernourished (UN, 2010) and the FAO estimates that food production needs to increase by $70 \%$ in 2050 to feed the global population (FAO, 2009). Population growth and also the change seen in diet composition related to increased welfare levels (e.g. Alexandratos et al., 2006; Gerbens-Leenes and Nonhebel, 2005; Grigg, 1995; Keyzer et al., 2005; Lotze-Campen et al., 2006; Rosegrant et al., 2001b; Smil, 2001; Vinnari and Tapio, 2009), with increased demand for animal products in developing countries, will increase future demand and resource utilization. Therefore, (future) use of natural resources in agriculture has been of critical interest to researchers, especially the use of water (e.g. Hoekstra and Chapagain, 2009; Hoekstra and Mekonnen, 2012; Van ham et al., 2013; WWF, 2012), land (e.g. Bruinsma, 2009; Fischer et al., 2002; Lotze-Campen et al., 2006; Wackernagel et al., 2002) and fertilizers (e.g. Galloway et al., 2007; Leach et al., 2012).

The aim of this study (Odegard, 2011) was to design four global 'What if...?' food scenarios for the year 2050 and to evaluate these quantitatively with respect to their use of the three main natural resources in agriculture: land, water and fertilizers. The question of whether we have the resource base to support the growing diet demand

\footnotetext{
* Corresponding author at: CE Delft, Oude Delft 180, 2611 HH Delft, The Netherlands. Tel.: + 31152150150 .

E-mail addresses: odegard@ce.nl (I.Y.R. Odegard), voet@cml.leidenuniv.nl (E. van der Voet).
}

deserves special attention because of the substantial share agriculture has in our use of natural resources and the major impact of agriculture on our environment. Worldwide, agriculture is a main contributor to environmental problems such as climate change, deforestation, eutrophication of water bodies, salinization of soils and depletion of water resources (Foley et al., 2005; Nakicenovik et al., 2000; Tilman et al., 2001; Vitousek et al., 1997). Several (scenario) studies concerning agriculture and natural resources use have been done (e.g. Bruinsma, 2009; Ewert et al., 2005; Liu and Savenije, 2008; Rosegrant et al., 2001a; Tilman et al., 2001; Wirsenius et al., 2010). The aim of this scenario study, which has not, to the authors' knowledge been done before, is to give a quantification of global land use, water use and fertilizer use $(\mathrm{N}, \mathrm{P}$ and $\mathrm{K}$ ) in 2050 for a complete diet for a global population, for four different futures and compare it to resource use in the year 2005 and to the total resource base.

This study integrates three sub-studies:

1) Four food scenarios were designed, based on the IPCC SRES (Nakicenovik et al., 2000), quantified for the year 2050. The food scenarios include different trends related to population, economic development, policy, technological development and diet. The 4 IPCC regions also used here are: the OECD90 region (countries in the OECD in 1990), the REF region (the countries under reform such as the former Soviet Union), the ASIA region (Asia) and the ALM region (Africa, Latin America and the Middle East).

2) A methodology was developed - virtual resource content - with which the use of resources in agriculture was calculated. Factors for virtual land content, virtual water content and virtual fertilizer 
content (for N, P and K fertilizers separately) were established, which are all quantifications of required input per output.

3) A model was created, with which the scenarios were quantified with respect to their resource use. For a given diet demand the model calculates resource use per commodity group, per region and per scenario.

\section{Material and Methods}

\subsection{Virtual Resource Content in Agriculture}

To quantify resource use in agriculture in 2050 virtual resource content (VRC) factors were established (Odegard, 2011). The rationale for the VRC factors is based on the 'virtual water content' concept developed by Hoekstra and Chapagain (2008), which refers to the volume of freshwater needed to produce a product.

Virtual resource content factors were quantified to encompass the required input of land (ha $\left.\mathrm{kg}^{-1}\right)$, water $\left(\mathrm{m}^{3} \mathrm{~kg}^{-1}\right)$ and fertilizer $\left(\mathrm{kg} \mathrm{N} / \mathrm{P} / \mathrm{K} \mathrm{kg}^{-1}\right.$ ) per commodity group, per region and per scenario. When coupled to consumption projections, actual resource utilization can be calculated. This way, comparisons to e.g. total suitable land can be made, showing requirement vs. availability.

The VRC concept is a component of footprint methodology. A 'footprint' is a very useful indicator of resource use, which illustrates our environmental impact and can be expressed as a share of the earth's carrying capacity. Footprint methodology (e.g. the Ecological Footprint, the Carbon Footprint, the Water Footprint and the Nitrogen Footprint) takes a life cycle approach (Galli et al., 2012; Hoekstra, 2009; Leach et al., 2012; Wackernagel et al., 2002). Because the (global or regional) resource requirements calculated here refer to only part of the life cycle we chose not to call these "footprints".

\subsubsection{Virtual Land Content (VLC)}

Virtual land content (ha/tonne) is the inverse of yield. Scenario characteristics were assumed to influence future yields; it was assumed that technological development and economic development would result in a larger closure of the yield gap (the difference between the present and the maximum attainable yield (MAY) of a certain crop) in 2050. Total land use is compared to global estimates of land suitable for agriculture.

2.1.1.1. Virtual Land Content Data. Cereal yield projections were extracted from (De Fraiture and Wichelns, 2010). They assume that in an "optimistic scenario" $80 \%$ of the yield gap (difference between current yield and maximum attainable yield) is bridged, while in a "pessimistic" scenario $20 \%$ of the yield gap is bridged. Economic and technological development is high in the A1 and B1 scenarios, thus for these scenarios a bridging of $80 \%$ of the yield gap was chosen. Development in the A2 scenario is low, which makes bridging the yield gap with $20 \%$ reasonable. The yield gaps were calculated using the 2005 yield (according to FAOSTAT) and the maximum attainable yield (MAY) for high input levels under rainfed conditions. Such MAYs were defined by the FAO and the IIASA (Fischer et al., 2002). These MAYs are given for crops, not for commodity groups. To estimate MAYs for commodity groups in the different regions, the crop MAYs are averaged according to the proportion of production of the main crops in the respective commodity group in 2005, thereby assuming that the relative production stays the same. As the MAYs for these crops were determined for rainfed conditions, the upper boundary (representing the most productive cultivar) was chosen to compensate for the lower maximum yields under rainfed conditions. No MAY data was given for fruits and vegetables; maximum attainable yields were based on the average of the regional 'best practice'; the average of the highest three yields achieved regionally for the whole commodity group.

The extent of land available in the four regions was estimated using data from the Global Agro-Ecological Zones study by the FAO and the IIASA Fischer et al., 2002. It is assumed that similar yields can be attained on very suitable, suitable and moderately suitable areas which may lead to overestimation of attainable production quantities, because yields are most likely lower on less suitable areas.

\subsubsection{Virtual Water Content (VWC)}

The virtual water content factors are measured in $\mathrm{m}^{3} /$ tonne, and are based on the crop evapotranspiration rates calculated by Hoekstra and Chapagain (2008). Scenario characteristics were assumed to influence irrigation efficiency, which is included for cereals, the main irrigated crop group. Total water use is compared to the regional renewable water resources.

2.1.2.1. Virtual Water Content Data. Virtual water content is based on the assessment of crop evapotranspiration rates as assessed by Hoekstra and Chapagain (2008). These are based on current agricultural management practices. For the commodity groups roots and tubers, pulses, vegetables and fruits, the global average water appropriations $\left(\mathrm{m}^{3} /\right.$ tonne) are assumed to be reasonable estimates for regional water use because of their relatively low contribution to total water consumption in agriculture. Adjustments were made to account for regional differences for commodity groups which account for large shares of the total global water use: the commodity groups cereals, oil crops and sugar crops. These adjustments on the regional level were based on the different production rates of five primary crops (i.e. rice, wheat, maize, soybeans and sugar cane) in the regions. It was assumed that relative production of these primary crops with respect to the total production of the commodity group will remain the same as it was in 2005. Irrigation is taken into account for cereals; irrigation inefficiencies raise water requirements for cereals to higher levels in the different scenarios. Cereal irrigation efficiency is based on assumptions made by De Fraiture and Wichelns (2010). Because pastures and such are generally not included in water use calculations they are excluded here.

\subsubsection{Virtual Fertilizer Content (VFC)}

Virtual fertilizer content is defined in fertilizer requirement per $\mathrm{kg}$ of crop output, for each of the three macro-fertilizers $(\mathrm{N} / \mathrm{P} / \mathrm{K})$ separately. Because phosphate rock and potash are finite resources, predictions of years of use remaining (in 2050) are made if the management as defined for 2050 would continue, based on reserves of these resources. Requirements were based on crop responses to nutrients or nutrient removal by crops, converted to pure nutrient values (e.g. $\mathrm{K}$ instead of $\left.\mathrm{K}_{2} \mathrm{O}\right)$.

2.1.3.1. Virtual Fertilizer Content Data. Recommended fertilizer use varies with crop, region, local soil characteristics and management practices. Actual fertilizer use may, however, depend on factors that have nothing to do with proper agricultural management, e.g. subsidies may raise fertilizer use well above recommended values. On the other hand, the proper application methods and timing can significantly reduce use rates, without reducing yields, and can thus increase efficiency (Smil, 2001). Fertilizer use is reported in FAOSTAT, for $\mathrm{N}, \mathrm{P}_{2} \mathrm{O}_{5}$ and $\mathrm{K}_{2} \mathrm{O}$ fertilizers separately, but is not specified per commodity group or crop, and is therefore only valuable as a measure for comparison of aggregated values (FAOSTAT, 2011). The FAO does report fertilizer use per country per crop in their FERTISTAT database (FERTISTAT, 2007). This gives insight into regional differences in current fertilizer application rates, but does not give insight into requirements and nutrient removal. Furthermore, it does not give insight into input per output, as the yields of these crops to which the fertilizer applications apply are not reported.

In this scenario study the fertilizer requirements were based on fertilizer response (in the case of $\mathrm{N}$ for cereals), or nutrient removal or uptake by the crop (per tonne of product) as reported by the FAO (FAO, $1984,2000,2006$ ). Data are given for different crops, not for cropgroups, so fertilizer requirements for the cropgroups were based on differences in the types of crops grown, and the share of the major crops in the 
group and region for cereals, sugar crops and roots and tubers. For these cropgroups world production is represented by 2 or 3 crops, which makes averaging in different regions possible. For the other cropgroups fertilizer requirements were based on the weighted average (based on the share in global production) of a few main crops. For the fodder types a distinction was made between temperate grasslands (assumed applicable to the OECD90 and REF regions) and tropical grasslands (assumed applicable to the ASIA and the ALM regions). For both types of grasslands the requirements were based on (IFA, 1992). The harvested pasture feed types were assumed to be harvested, for which $\mathrm{P}$ and K application is assumed necessary. 'Pasture' was assumed to be partially fertilized by manure under grazing, with no extra need for $\mathrm{P}$ and $\mathrm{K}$ fertilizer.

In case data for removal or uptake of nutrients by the crop are used, projections may lead to underestimation of fertilizer use because of losses in the field and uptake by other plant parts, e.g. leaves and roots. On the other hand, use of manure ${ }^{1}$ or green manure was not taken into account here. For leguminous crops, adjustments were made to the $\mathrm{N}$-requirements; $\mathrm{N}$-requirements were lowered to account for biofixation. Because, in the last decades, fertilization rates in the developed world were relatively high, soils may contain sufficient $P$ to justify application of the amount removed by the crop (Sattari et al., 2012). This is not true for the developed world, for which phosphate is often a limiting factor in attaining higher crop yields (Sattari et al., 2012; Steen, 1998). Therefore, application rates higher than the removal rates would be necessary to increase yields according to the scenario characteristics assumed.

\subsection{Scenarios}

This study describes four food scenarios: the Affluent World (A1), the Full World (A2), the Vegetarian World (B1) and the Low-Input World (B2). The design was based on the scenarios developed by the International Panel on Climate Change (IPCC) in their Special Report on Emission Scenarios (SRES) (Nakicenovik et al., 2000). The four scenarios are aligned along 2 axes; the vertical indicating a focus on economy (the ' $\mathrm{A}$ ' scenarios) or environment (the 'B' scenarios), the horizontal indicating a focus on globalization (the ' 1 ' scenarios) or regionalization (the '2' scenarios). The food scenarios with a focus on globalization (the Affluent World/A1 and the Vegetarian World/B1) are evaluated on a global scale (trade is considered free). Four regions were defined by the IPCC; the Full World/A2 and the Low-Input World/B2 scenarios are evaluated on a regional level. Because trade between regions is not modeled, the regional scenarios evaluate regional self-sufficiency.

Four driving forces defined by the IPCC were taken into account: population, economic development, technological development and policy. A quantitative description of the scenario characteristics and assumptions is given in Table 1 and Sections 2.2.1 and 2.2.2.

The direction (a focus on economy or environment) and pace of trends related to technological development and policy were based on the IPCC trends, but interpreted to fit our food scenarios. This focus on economy or environment is also assumed to be the main driver in projections concerning consumption patterns, which was added as a fifth driving force. A wide variety of diet trends, from 'Western' to vegetarian, is considered, to ensure a broad range of outcomes.

The scenarios are quantified for a complete diet. This includes the seven vegetable commodity groups cereals (rainfed and irrigated),

\footnotetext{
${ }^{1}$ Use of manure as a source of fertilizer seems to be stabilizing, according to an indication of the sources of phosphorus used as fertilizer by Cordell et al. (Cordell et al., 2009). According to Cordell at al., phosphorus fertilizer use amounted to around 20 Mtonnes in 2005 , very close to the calculation made here for 2005 . Of this amount, manure accounts for around 3 Mtonnes per year, and this value seems to be stable since around 1970. There are many reasons why manure is a less attractive nutrient source than synthetic fertilizers; e.g. nitrogen in manure is more volatile, which leads to higher losses. Furthermore, it is not attractive to transport manure over large distances, which limits the practical use.
}

fruit, oil crops (which includes vegetable oils), pulses, roots and tubers, sugar crops (which includes sugar and sweeteners), and the animal products meat (pork, beef and chicken), milk and eggs. The combination of a varied set of the main vegetable commodity groups and animal commodity groups ensures that calorically and nutrient-wise, a complete diet is evaluated and the results can be interpreted as such.

\subsubsection{Population, Economic Development and Diet}

The basis for the diet demands are the projections made by the FAO (Alexandratos et al., 2006). Global and regional diets were based on these FAO projections for corresponding levels of economic development and geographical location. In all scenarios and regions, caloric intake is increased to eliminate undernutrition. Adjustments to and additional assumptions about the 'apparent consumption' of meat, milk, eggs, sugar, oil crops, fruits, vegetables and pulses were made (see Table 1). Quantification of meat consumption in the A scenarios is based on the level of economic development, for which Keyzer et al. found a relation to meat consumption (Keyzer et al., 2005). The Vegetarian World/B1 scenario presents a vegetarian scenario, while the LowInput World/B2 scenario cuts consumption of meat in half according to the projection based on the 'Keyzer equation'.

The quantitative projections for population growth were based on the population projections by the UN in 2008 and IIASA in 2009 (Lutz et al., 2008; UN, 2009) used in the IPCC scenarios. Since the release of the IPCC report in 2000, the population projections have been updated by the UN and by the IIASA; both updates were used in this study. The UN projections are defined on a country level, and aggregated to the regional and global scale. The IIASA projections are defined on a regional level, for a total of 13 regions. Groups of IIASA regions correspond to the IPCC regions. Updated projections for economic development were obtained from the PBL (Van Vliet, 2010), for a total of 17 regions. These projections of economic development were used to project future meat consumption in the A scenarios. The meat consumption projections were based on the set of equations given in (Keyzer et al., 2005), which quantify the relationship between purchasing power parity (PPP) and meat consumption per capita. However, the 13 IIASA regions do not correspond to the 17 regions in the projections of economic development. Therefore meat consumption per capita was calculated on a country level. GDP in PPP per country was assumed equal to the projection for the region to which the country belongs. The proportion between the national populations (for the high and low growth projections) in 2050, was assumed equal to the proportion in the regional population in 2005. The type of meat consumed was not defined by Keyzer et al. Therefore, the proportion bovine meat:poultry:pork in 2050 was assumed equal to that proportion in the year 2005; namely $26 \%$ bovine meat, $33 \%$ poultry and $41 \%$ pork (FAOSTAT, 2011 ).

\subsubsection{Feed Mixes and Feeding Efficiency}

Feed requirements for the animal products are taken into account, and comprise twelve different inputs. Five of these are also foodcrops: cereals, oil crops, roots and tubers, pulses and vegetables, one is a feedcrop: whole maize. Three are by-products of harvesting, processing or consumption and then there is pasture and harvested pasture. The feedmixes and feeding efficiencies are based on (Wirsenius, 2000). Household and retail waste is lower in the $B$ scenarios because of higher environmental consciousness, while it is lower in the Full World/A2 scenario because of lower economic development.

Five animal product systems with product system specific feed mixes were considered. Buffalo, sheep and goat meat are grouped under 'cattle, beef', as they are similar in their requirements and efficiency. Feed mixes and feeding efficiencies were obtained from Wirsenius (2000). All phases of animal husbandry are included, e.g. reproduction, replacement, gestation and lactation. The feed mixes are composed of 14 different ingredients. Not all of these are included in the feed mix for each of the five animal systems; e.g. feed for cattle is assumed to be primarily grass, poultry have a preference for cereals, while 
Table 1

Qualification and quantification of scenario assumptions and characteristics for 2050

\begin{tabular}{|c|c|c|c|c|}
\hline \multirow[t]{2}{*}{ Topic } & \multirow{2}{*}{$\begin{array}{l}\text { A1 - The Affluent World } \\
\text { Global \& economy }\end{array}$} & \multirow{2}{*}{$\frac{\mathrm{A} 2-\text { The Full World }}{\text { Regional \& economy }}$} & \multirow{2}{*}{$\frac{\text { B1 - The Vegetarian World }}{\text { Global \& environment }}$} & \multirow{2}{*}{$\frac{\text { B2 - The Low-Input World }}{\text { Regional \& environment }}$} \\
\hline & & & & \\
\hline $\begin{array}{l}\text { Population growth } \\
\text { (pop. in 2050) }\end{array}$ & $\begin{array}{l}\text { Low }-7.78 \text { billion } \\
\text { (Lutz et al., 2008) }\end{array}$ & $\begin{array}{l}\text { High }-9.9 \text { billion } \\
\text { (Lutz et al., 2008) }\end{array}$ & $\begin{array}{l}\text { Low }-7.78 \text { billion } \\
\text { (Lutz et al., 2008) }\end{array}$ & $\begin{array}{l}\text { Medium - } 9.15 \text { billion } \\
\text { (UN, 2009) }\end{array}$ \\
\hline $\begin{array}{l}\text { Economic development } \\
\text { (av. global income per capita in PPP } \\
\text { (Van Vliet, 2010) }\end{array}$ & High $-28,400$ US\$-1995 & Low - 11,900 US\$-1995 & Med-high - 22,200 US\$-1995 & Medium - 17,700 US\$-1995 \\
\hline $\begin{array}{l}\text { Technological development; relates to } \\
\text { productivity of foodcrops and } \\
\text { feedcrops and feeding efficiency }\end{array}$ & Rapid and global & Slow and regional & Medium and global & Medium and regional \\
\hline $\begin{array}{l}\text { Diet demand } \\
\text { (Based on Alexandratos et al., } 2006 \\
\text { p.25 and Keyzer et al., 2005) }\end{array}$ & $\begin{array}{l}\text { Western diet. Basis: 'industrial } \\
\text { countries in 2050' (FAO). } \\
\text { Average global meat } \\
\text { consumption: } 93 \mathrm{~kg} / \mathrm{cap} / \text { year. } \\
\text { Share (in kcal) of animal based } \\
\text { foods in the diet: } 26 \% \text {. } \\
\text { Consumption of fruit, vegetables, } \\
\text { eggs, oil crops and sugar crops are } \\
\text { set to average global } 2005 \text { levels } \\
\text { (FAOSTAT, 2010) }\end{array}$ & $\begin{array}{l}\text { Western diet. Basis: 'diets in } \\
\text { 2030' (FAO). (OECD90: } \\
\text { industrial countries, REF: } \\
\text { transition countries, ASIA/ALM: } \\
\text { developing countries). Average } \\
\text { global meat consumption: } \\
62 \mathrm{~kg} / \mathrm{cap} / \text { year. Share (in kcal) } \\
\text { of animal based foods in the } \\
\text { diet: } 22 \% \text {. } \\
\text { Consumption of fruit, } \\
\text { vegetables, eggs, oil crops and } \\
\text { sugar crops idem to A1 }\end{array}$ & $\begin{array}{l}\text { Vegetarian diet. Basis: 'global } \\
\text { average in 2050' (FAO). Share (in } \\
\text { kcal) of animal based foods in the } \\
\text { diet: } 9 \% \text {. Higher consumption of } \\
\text { milk, eggs, oil crops and pulses to } \\
\text { increase protein content. Also } \\
\text { higher in fruits and vegetables, } \\
\text { and lower in sugar because of } \\
\text { health considerations (based on } \\
\text { OECD, 2010) }\end{array}$ & $\begin{array}{l}\text { Reduced meat diet. Basis: 'diets } \\
\text { in } 2050 \text { ' (FAO). Share (in kcal) } \\
\text { of animal based foods in the } \\
\text { diet: } 17 \% \text {. (OECD90: industrial } \\
\text { countries, REF: transition } \\
\text { countries, ASIA/ALM: } \\
\text { developing countries). Average } \\
\text { global meat consumption: } \\
37 \mathrm{~kg} / \mathrm{cap} / \text { year, higher in fruits } \\
\text { and vegetables, and lower in } \\
\text { sugar }\end{array}$ \\
\hline $\begin{array}{l}\text { Apparent consumption } \\
\text { (based on Alexandratos et al., 2006) }\end{array}$ & Average $>2900 \mathrm{kcal} \mathrm{cap}^{-1}$ day $^{-1}$ & $\begin{array}{l}\text { Regional average }>2900 \mathrm{kcal} \\
\mathrm{cap}^{-1} \mathrm{day}^{-1}\end{array}$ & Average $>2800 \mathrm{kcal} \mathrm{cap}^{-1} \mathrm{day}^{-1}$ & $\begin{array}{l}\text { Regional average }>2800 \mathrm{kcal} \\
\text { cap }^{-1} \text { day }^{-1}\end{array}$ \\
\hline $\begin{array}{l}\text { Household \& retail waste } \\
\text { (based on Kantor et al., 1997) }\end{array}$ & $\begin{array}{l}\text { Levels correspond to 1995-USA } \\
\text { levels }\end{array}$ & Half of level in A1 & Half of level in A1 & Half of level in A1 \\
\hline $\begin{array}{l}\text { Productivity foodcrops (based on De } \\
\text { Fraiture and Wichelns, 2010) }\end{array}$ & $80 \%$ closure of yield gap & $20 \%$ closure of yield gap & $80 \%$ closure of yield gap & Yields: half of A2 yields \\
\hline $\begin{array}{l}\text { Productivity feedcrops } \\
\text { (based on Wirsenius, 2000) }\end{array}$ & $\begin{array}{l}\text { Due to intensive management, } \\
\text { the yield is the same as in } \\
\text { Western Europe }\end{array}$ & $\begin{array}{l}\text { Some intensive management, } \\
\text { yields vary between global } \\
\text { average and Western Europe }\end{array}$ & $\begin{array}{l}\text { No intensive management; yields } \\
\text { correspond to global average }\end{array}$ & $\begin{array}{l}\text { No intensive management; } \\
\text { yields correspond to global } \\
\text { average }\end{array}$ \\
\hline $\begin{array}{l}\text { Feeding efficiency (based on reg. } \\
\text { efficiencies in Wirsenius, 2000) }\end{array}$ & $\begin{array}{l}\text { Global efficiency equal to current } \\
\text { efficiency in North America } \\
\text { region }\end{array}$ & $\begin{array}{l}\text { Highest efficiency } \\
\text { corresponding to } \\
\text { geographically nearest region }\end{array}$ & Idem to A1 & Idem to $\mathrm{A} 2$ \\
\hline $\begin{array}{l}\text { Irrigated area (cereals only) } \\
\text { (based on De Fraiture and Wichelns, } \\
\text { 2010) }\end{array}$ & $\begin{array}{l}75 \% \text { of } 454 \text { million hectare under } \\
\text { irrigation for cereals. }\end{array}$ & $\begin{array}{l}75 \% \text { of } 453 \text { million hectare } \\
\text { under irrigation for cereals. }\end{array}$ & $\begin{array}{l}75 \% \text { of } 363 \text { million hectare under } \\
\text { irrigation for cereals. }\end{array}$ & $\begin{array}{l}75 \% \text { of } 363 \text { million hectare } \\
\text { under irrigation for cereals. }\end{array}$ \\
\hline Cereal irrigation efficiency & $\begin{array}{l}\text { 60\% (based on De Fraiture and } \\
\text { Wichelns, 2010) }\end{array}$ & $60 \%$ (id) & $65 \%$ (id) & $65 \%$ (id) \\
\hline Fertilizer efficiency gain & $10 \%$ & $0 \%$ & $15 \%$ & $15 \%$ \\
\hline
\end{tabular}

pigs prefer forage crops. To include a measure of (technological) development in the scenarios, the feed mixes defined by Wirsenius for the 'North America and Oceania' region were chosen to represent the global feeding efficiency in 2050 in the A1 and B1 scenario because it is the most efficient in terms of the weight of the feed input defined in dry matter (DM). Four of the Wirsenius regions were chosen to represent the four regions in the A2 and B2 scenarios, based on geographical correspondence combined with highest efficiency. In the model, for the reference year (2005), feed mixes and efficiencies were represented by the global average in 1993 (as defined in Wirsenius, 2000). Some progress and development have taken place since then, but it was found that these data are a reasonable approximation to the situation in the year 2005, as reported by the FAO (FAOSTAT, 2011). Overall, in DM, the calculated total feed was only $0.1 \%$ higher than the FAO estimate.

\subsection{Food System Model}

A physical input-output model was built in Matlab to quantify the scenarios. It calculates natural resource requirements for production of a certain diet demand. Fig. 1 shows the structure of the food system model as well as the linkages between the topics related to the different driving forces (as qualified and quantified in Table 1).

The link between production and natural resource use is determined by the 'virtual resource content' (see Section 2.1). As shown in Table 1, yield projections per commodity group are determined per scenario. Irrigation efficiency and fertilizer efficiency are incorporated as adjustable parameters.
Three topics deserve further explanation; conversion factors for sugar and oil, availability of by-products which are used as feed, and the losses that occur in the food chain. Because virtual resource content factors are defined for primary products (i.e. oil crops instead of vegetable oils) consumption of vegetable oils and sugar and sweeteners need to be converted back to the primary product. It was assumed that current (2005) global extraction rates for the FAO groups 'vegetable oils' from 'oil crops' and 'sugar and sweeteners' from 'sugar crops' remain constant. This means an average extraction rate of $36 \mathrm{wt}$.\% for vegetable oils from oil crops and 12 wt.\% for sugar and sweeteners from sugar crops.

Economically available amounts of harvest by-products, processing by-products and non-eaten food, all used as feed, were assumed to be limited to $50 \%$ of the produced total (a methodology also applied in (Wirsenius et al., 2010)). Additional feed requirements were assumed to be supplied by the most appropriate crop for the specific animal: pasture for cattle, forage for pigs and cereals for poultry.

As for losses, because trade is not included in the scenarios and current data provide insufficient insight into flows of foodstuffs and their purpose, the fraction of food used for purposes other than food or feed (i.e. seed, waste (during transport, storage and processing), processing and other utilities) was assumed constant relative to the total production quantity, across all regions.

\section{Results}

In this section the results with respect to resource use in the four scenarios will be given. Section 3.1 discusses land use in 2050, Section 3.2 


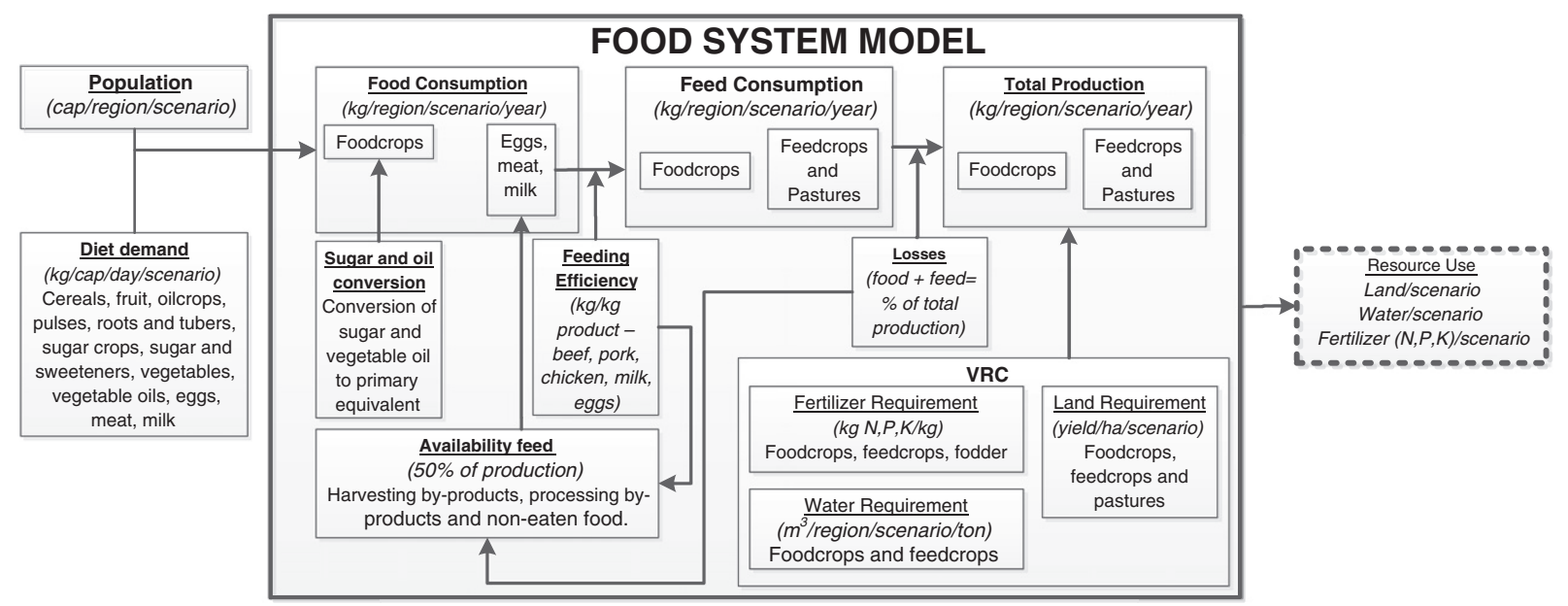

Fig. 1. Linkages between driving forces and input parameters in the food system model.

elaborates on water use in 2050 and Section 3.3 on fertilizer use in 2050. Section 3.4 will take a look at the whole picture of resource use per scenario. All these quantifications are based on the quantification of total production, as shown in Fig. 2.

Table 2 presents the composition of the total food supply per capita, including feed, wastes and losses. This illustrates the relatively high contribution of meat to the total production.

\subsection{Land Use in 2050}

Land is used to grow foodcrops (which are also used for purposes other than food such as feed) and feedcrops (for which agriculturally suitable land is required), and as pastures and grasslands to feed animals. Fig. 3.a shows the total global cropland use (in harvested area) for the year 2005 and the four scenarios.

The horizontal lines indicate the area suitable for agriculture; aggregations of the three main quality classes of land: very suitable (VS), suitable (S) and moderately suitable (MS), were used as a reference. It was assumed that between $70 \%$ and $90 \%$ of the land suitable may be available (in line with Fischer et al., 2002). The bars in the figure show the harvested area, while the threshold-lines show actual available land. Actual land use may be lower if the aggregated cropping intensity is higher than $100 \%$. Currently, the global average cropping intensity is lower than $100 \%$, because the total area of arable land and permanent crops - around 1.5 billion ha in 2005 (FAOSTAT, 2011) - is a little higher than the harvested area.

The main factors which create the differences between the scenarios are meat consumption, feeding efficiency and yield projections. For example, average apparent consumption in kcal per capita is around 15\% higher in the Affluent World/A1 than in the Full World/A2. But even though yields are much higher in A1 than in A2, harvested cropland area per capita is around $17 \%$ higher in A1 than in A2.

Total land use - including pastures - shows that a combination of high yields, high feeding efficiencies and intensive management of pastures decreases total land use in A1. While aggregated total production is higher in A1 than in A2, total land use is much higher in A2, as shown in Fig. 3.b. Due to a much lower consumption of animal products and higher feeding efficiencies and yields, total land use in the Vegetarian World/B1 - including pastures - is lower than cropland use in 2005 (land use excluding pastures and such).

When focusing on the four regions in the Full World/A2 and the LowInput World/B2 scenarios, it shows that land use increases in all regions for both scenarios. In the Full World/A2, the ASIA region will not be able to be self-sufficient, even when assuming a cropping intensity of $138 \%$ on irrigated lands (current estimated average, based on AQUASTAT, 2011). The REF region comes very close to reaching the lower limit of available suitable land. In the Low-Input World/B2 the demand exceeds the available land area in all regions.

\subsection{Water Use in 2050}

Fig. 4.a shows the total global water use for the year 2005 and the four scenarios. Direct water use by animals (i.e. drinking water) is insignificant compared to the water needed to grow crops: it adds up to around $0.1 \%$ of total water use (based on Smil, 2001), and is not shown in the figure. The lines in Fig. 4.a indicate the global thresholds (based on FAO criteria (Bruinsma, 2003)) for moderate water stress (solid line, $20 \%$ of renewable water resources) and critical stress (dotted line, $40 \%$ of renewable water resources). In 2005, 23 countries experienced moderate water stress, while 49 experienced critical water stress (based on data from Hoekstra and Chapagain, 2008). As Fig. 4.a shows, high feeding efficiencies come at a price: high water use in agriculture.

The fact that water use in 2050 in the Affluent World/A1 and the Full World/A2 scenarios exceeds the moderate water stress threshold, and that the Low-Input World/B2 scenario comes quite close to that threshold, indicates that many countries will experience water stress in 2050. The slightly higher irrigation efficiency, a raise from $60 \%$ to $65 \%$, saves respectively $3 \%$ and $1.5 \%$ of total water use in the Vegetarian World/B1 and the Low Input-World/B2.

Comparing global water use to global average water stress thresholds may, however, underestimate regional issues. Fig. 4.b and c shows the regional situations for the Full World/A2 and the Low-Input

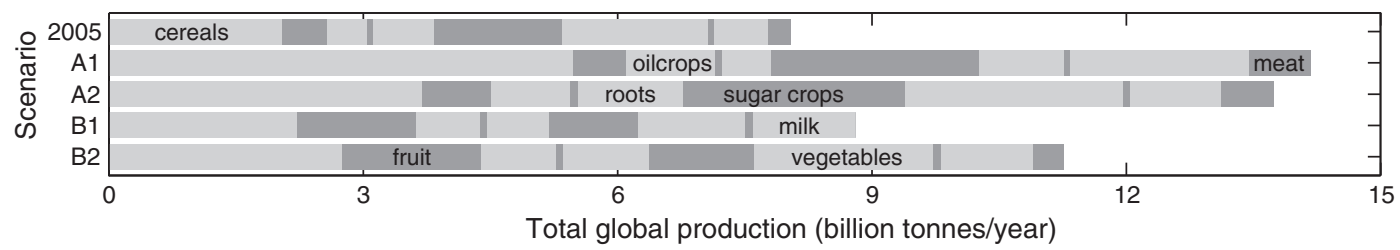

Fig. 2. Total production. Stack order: (left to right): cereals, fruit, oil crops, pulses, roots and tubers, sugar crops, vegetables, eggs, milk, meat. 
Table 2

Food supply per capita per day (kcal) in 2005 and in the four scenarios in 2050.

\begin{tabular}{lrrrrr}
\hline & \multicolumn{7}{c}{ Food supply (kcal/capita/day) } & & \\
\cline { 2 - 6 } & 2005 & \multicolumn{1}{c}{ A1 } & \multicolumn{1}{c}{ A2 } & \multicolumn{1}{c}{ B1 } & \multicolumn{1}{c}{ B2 } \\
\hline Losses & 865 & 1688 & 1035 & 909 & 931 \\
Feed & 1207 & 3847 & 1446 & 647 & 871 \\
Household and retail waste & 321 & 835 & 375 & 366 & 369 \\
Consumption & 2155 & 2541 & 2572 & 2386 & 2478 \\
Total production & 4549 & 8911 & 5428 & 4307 & 4648 \\
\hline
\end{tabular}

World/B2 scenario (note that the values on the y-axis differ). In the A2 scenario, the ASIA region exceeds the moderate water stress threshold by $84 \%$, and is only $8 \%$ short of the critical water stress threshold. Currently, this region already experiences moderate water stress. The OECD90 region, the REF region and the ALM region come quite close to the moderate water stress threshold. In the Low-Input World/B2, water use in the ASIA region also exceeds the moderate water stress level, by $47 \%$. High water use in the ASIA region is mainly due to the higher production rate of cereals, specifically irrigated cereals. Furthermore, population growth in this region is quite high, and current food availability is inadequate. Population growth in the ALM region is also expected to be high, but as can be seen in Fig. 4.b and c, regional water availability is much higher there than in the ASIA region.

\subsection{Fertilizer Use in 2050}

It is important to distinguish between the three synthetic macro fertilizers, because phosphorus and potassium fertilizers are based on finite resources. Agricultural practices can have a significant impact on nutrient use; therefore fertilizer efficiencies are modeled higher in the two B scenarios (with a focus on environment) and in the Affluent World/A1 scenario in which technological development is high. Fig. 5.a, b and c respectively shows $\mathrm{N}, \mathrm{P}$ and $\mathrm{K}$ fertilizer used, quantified in terms of the nutrient weight (e.g. $\mathrm{kg} \mathrm{N}, \mathrm{P}$ or K) in 2005 and in the year 2050 for the four scenarios.

As fertilizer use is linked to production, the fertilizer use figures look like the figure showing total production (Fig. 2). The relative differences are a little more extreme because of the contribution of feed categories. The reserves, expressed in years of use at the 2050 level, are presented in Table 3. To quantify use rates relative to the reserve base (USGS, 2009), the use levels were assumed to increase linearly between 2005 and 2050. Total use between 2005 and 2050 was subtracted from the reserve base (which was assumed to be used only to produce fertilizers, even though around 20\% is used for different purposes (Steen, 1998)), after which the remaining reserve in years was determined based on use rates in 2050.

Surprising are the low potassium reserves. These low reserves in 2050 can be explained by the current gap between application of potassium fertilizer and the recommended application used to model the scenarios for 2050. Recommended use rates were based on nutrient removal by the crop, but potassium stored in the soil may be sufficient to support cultivation in many places for some time. Yields will be lower if potassium (or phosphorus or nitrogen) is available in limiting amounts (either due to lack of application as fertilizer or deficient soils). Furthermore, the known $\mathrm{K}$ resources are over 13 times the current reserve base (Roberts, 2008). The reserve base is partially based on economic availability. This means it is unlikely that we will run out of potassium in the near future, but also that the resource will become ever more expensive; another obstacle in reaching global food security.

\subsection{Resource Use in 2050}

As the analyses of resource use above have shown, land use is a problem in the Low-Input World/B2, while water use and fertilizer use is a problem in both the Affluent World/A1 and the Full World/A2. In the results for the A scenarios and the B2 scenario one can clearly see the negative correlation between land use and fertilizer use; while land use falls within global limits, fertilizer use exceeds desired rates (A1 and A2) or vice versa (B2). Only in the Vegetarian World scenario (B1) does use of natural resources stay within the earth's carrying capacity.

\section{Discussion}

The modeled water use compares well to figures given in the literature. Water use in agriculture in the year 2005 was modeled at a global use of $6019 \mathrm{~km}^{3}$ per year, which is somewhat lower than the estimate made by the Water Footprint Network of $6189 \mathrm{~km}^{3}$ per year (Hoekstra and Chapagain, 2008). The International Water Management Institute estimates water use in agriculture to be even higher: $7130 \mathrm{~km}^{3}$ per year (De Fraiture et al., 2007). This discrepancy can be due to two factors. Irrigation was not taken into account in modeling the 2005 situation, because irrigation data mainly focus on cereals (which is the main irrigated cropgroup) and data is not available on a global scale. This means that water use is slightly underestimated because irrigation efficiency is around 60\%. As can be seen in Fig. 4.a, in all scenarios the bulk of water use is required for cereals production. Furthermore, because certain commodity groups, i.e. stimulants, nuts and spices (totaling only $5.5 \%$ of global water use in agriculture in 2000 (Hoekstra and Chapagain, 2008)), are not taken into account, a lower modeled estimate for 2005 is reasonable.

a)

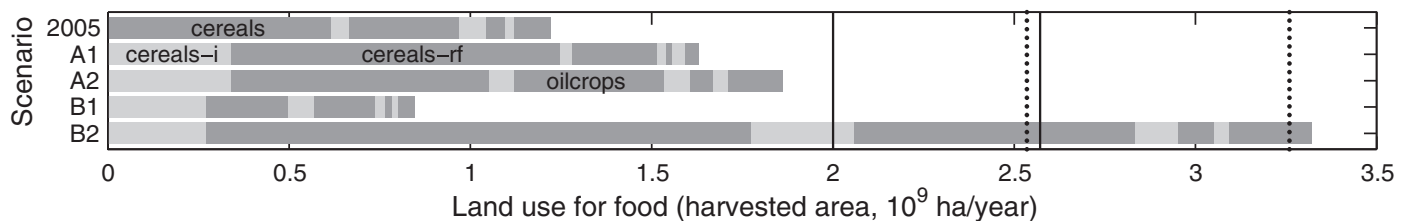

b)

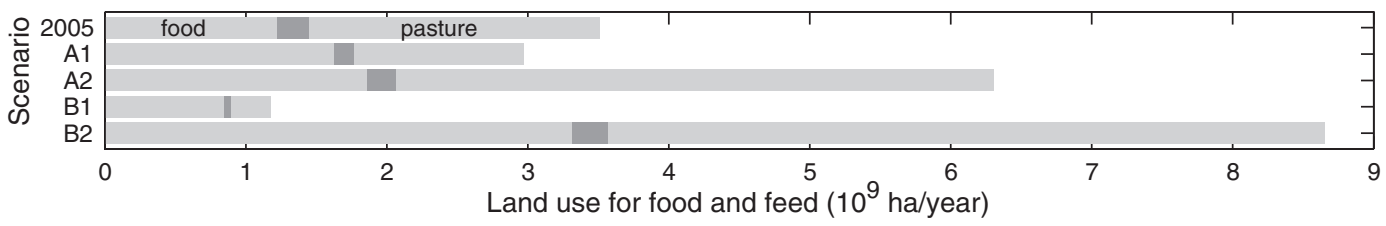

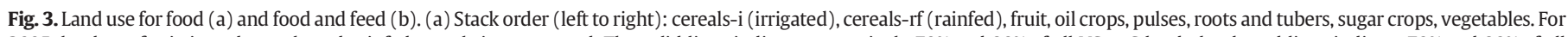

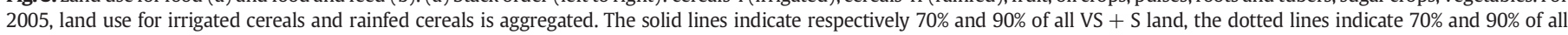
VS + S + MS land. (b) Stack order (left to right): food (the sum of the food groups shown in (a)), harvested feed, pasture. Note the scale difference of the x-axes. 
a)

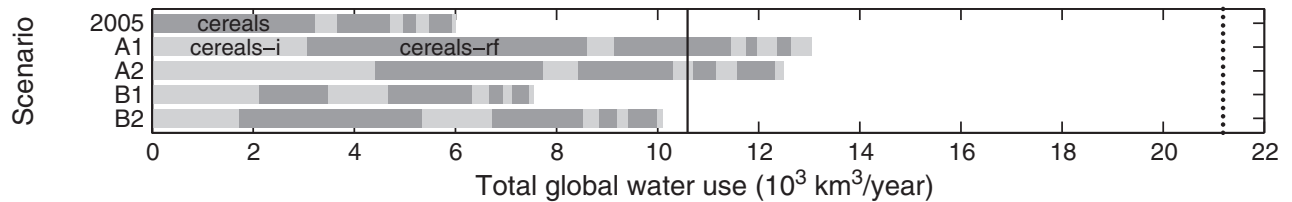

b)

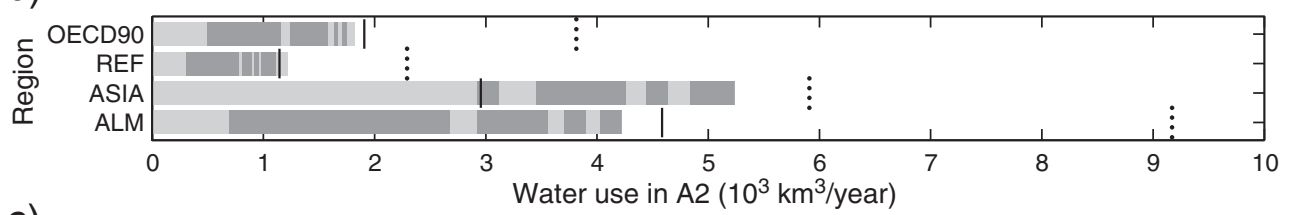

c)

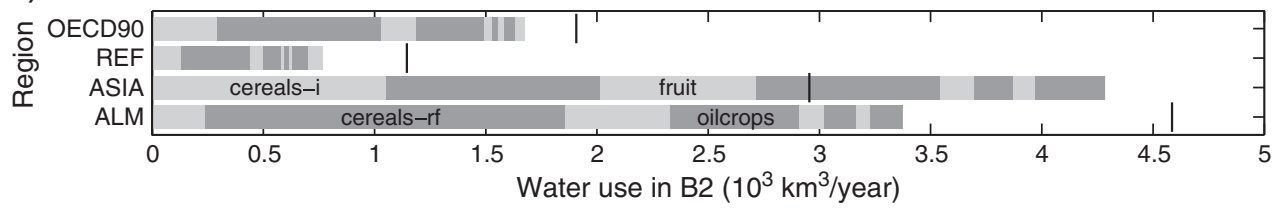

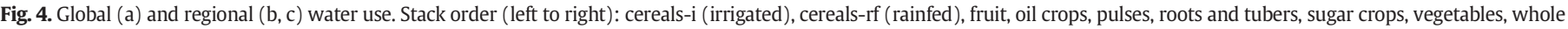

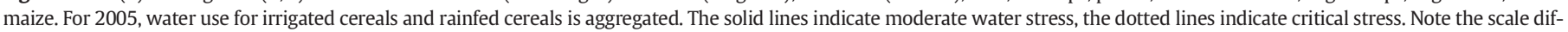
ference of the $\mathrm{x}$-axes.

There are several reasons why the results presented here can be seen as optimistic. First of all, resources are assumed to be spread equally either regionally or globally, e.g. the water stress levels are calculated as a percentage of the total renewable resources either regionally or globally. However, water use poses problems on local levels, which cannot be gathered from the data presented. The water projections presented are of the same order of magnitude as given in literature. For example, the International Water Management Institute projects an increase of $70 \%-90 \%$ in crop water use, depending on e.g. population growth and income, which would amount to an annual water consumption between 12,050 and 13,500 cubic kilometers (De Fraiture et al., 2007). This is in line with the projections made here for the Full World/A2 scenario $\left(12,500 \mathrm{~km}^{3} /\right.$ year) and the Affluent World/A1 (15,085 km³/year).

Secondly, after the modeling of these scenarios, population projections have been updated and are estimated to be higher than what was assumed here (UN, 2011). Thirdly, in line with IPCC reasoning (Nakicenovik et al., 2000), environmental degradation and climate change were not taken into account (although the latter may also improve agricultural conditions in certain areas), as well as (fossil) energy use, on which agriculture is very reliant. And finally, potential yields were assumed the same for all land qualities, which may lead to an overestimation of attainable production.

On the other hand, in the Vegetarian World/B1 scenario the production of beef products from milk cows and chicken products from hens was not included. 'Additional food' is thus available in the Vegetarian World/B1 and the final resource use in that scenario could be lower because the meat products could substitute part of the given diet. Also, fish was excluded from the analysis because the link to land use, water use and fertilizer use is much weaker and fish does not contribute much (in kcal per capita per day) to the global average diet. Regionally and

a)

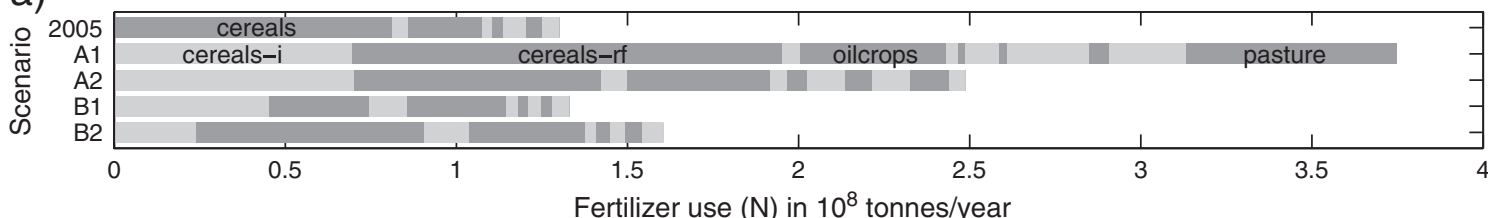

b)

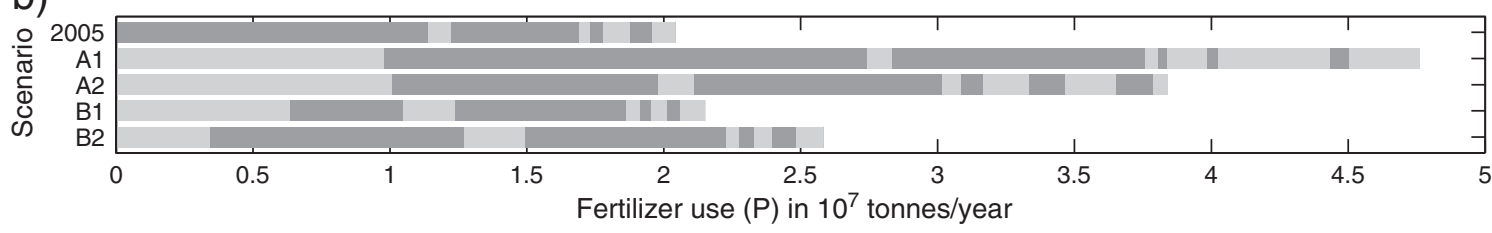

C)

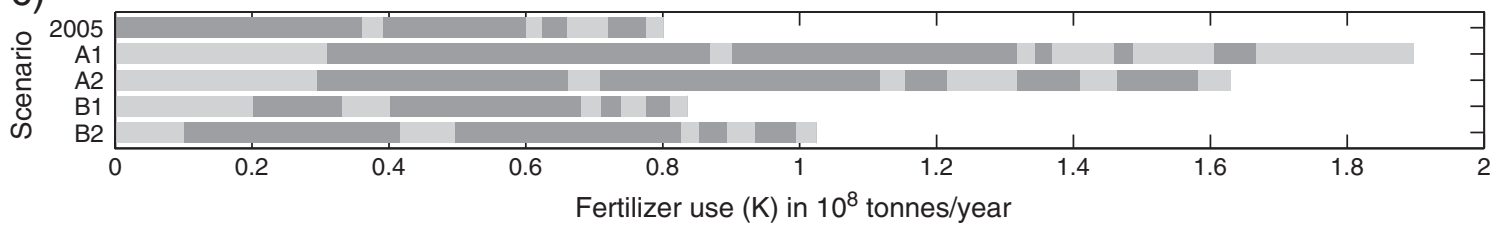

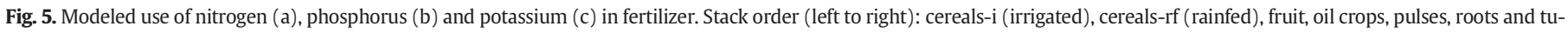

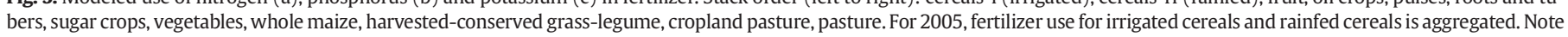
the scale difference of the $\mathrm{x}$-axes. 
Table 3

Fertilizer reserves in 2050 for P \& K at 2050-level.

\begin{tabular}{lllll}
\hline \multicolumn{5}{c}{$\begin{array}{l}\text { Nutrient reserves left in 2050 - years of use at 2050 level } \\
\text { (based on USGS (2009) reserve base) }\end{array}$} \\
\cline { 2 - 5 } & A1 & A2 & B1 & B2 \\
The Affluent & The Full & The Vegetarian & The Low-Input \\
& World & World & World & World \\
\hline P & 101 & 130 & 249 & 204 \\
K & 17 & 23 & 66 & 50 \\
\hline
\end{tabular}

locally though, fish may be very important. Furthermore, even though efficiency improvements have been incorporated into the scenarios for which this was fitting, innovative technologies may still improve the VRC-factors. Such technologies may take a while to disperse globally though, and the results of this study further stress the necessity to innovate in agriculture. And finally, more resource-efficient foods may become more prevalent in the future, such as insects (Van Huis et al., 2013) or cultured meat (Tuomisto and Roy, 2012).

Total fertilizer consumption has been growing steadily, from 31 Mtonne in 1961 to 141 Mtonne in 2002 (FAOSTAT, 2012). Projections concerning fertilizer use are difficult for various reasons. Historic and current use rates do not supply information on requirements, and soil quality can lower requirements on the short term. Furthermore, agricultural practices are important to fertilizer efficiency and can lower demand, for instance through proper crop rotations, planting green manure and using manure for fertilization. In this study, in a number of cases, fertilizer recommendations were based on nutrient removal by the crop, which may underestimate fertilizer requirements. On the other hand, manure applications were not taken into account. For phosphorus, the results presented here coincide with other projections of future phosphorus fertilizer availability (e.g. Cordell et al., 2009; EcoSanRes, 2008; Steen, 1998), which is a well-described problem. Potassium does not, however, get a lot of attention, even though potassium fertilizer is, like phosphorus, based on a non-renewable resource. There seems to be a gap between actual potassium use and potassium use rate recommendations. This may be due to an overestimation of requirements, although the method used to determine requirements was the same as for $\mathrm{P}$ and $\mathrm{N}$, which have shown to be good approximations. Otherwise, it is possible that current use rates are deficient in K; according to Smil, specifically in China, applications have been deficient in $\mathrm{P}$ and $\mathrm{K}$ (Smil, 2001). This may make it difficult to achieve substantial long-term yield increases. The results are alarming enough to at least deserve further elaboration in research and the attention of the food sector, policy makers and industry. The scenarios results show an undesirable future and emphasize the need to move towards a more cyclic agricultural system.

In any study aiming to give results on a global level, data availability and reliability is an issue. Therefore, when evaluating the results of the scenarios it is important to keep in mind that they are 'What if?' scenarios, based on a list of assumptions. If the quantifications to these assumptions would change, naturally, so would the results. It is important to remember that scenarios of this kind are not made to assess what will happen, but what could happen, given such a set of consistent assumptions. The results should also be evaluated in this light. The assumptions to which the results are especially sensitive are the apparent consumption and the losses and wastes; changes in diets and minimization of food losses and wastes could lower production rates significantly, while securing regional and global food security with equitable distribution. Unfortunately there does not seem to be a trend in such a direction.

Because economic variables such as prices were not taken into account, the effects on resource use were modeled given the assumption that a given demand is fulfilled. It is not reasonable, however, to assume that if this creates an unsustainable situation, such a situation would not occur. Such situations do occur at present, e.g. in countries in the Middle East using more than $100 \%$ of their renewable water resources in agriculture. The results show that trade-off issues are important and need to be addressed when discussing the future of food. An assessment of resource use is only valuable when a complete picture is given. Therefore, the present study provides valuable input for assessing problem areas, but also for identifying opportunities in our agricultural system.

\section{Conclusions}

From a demand-side perspective it can be concluded that current trends in animal product consumption cannot continue indefinitely due to lack of natural resources to support such a system. Moreover, a situation such as in the Affluent World/A1 where potassium fertilizers run out around 2070 would never progress to such a stage because fertilizer prices would have risen too much to justify such use. This study clearly illustrates the inequity in the food system: the lifestyles of many in the industrialized world cannot be supported on a global scale. One potential development could be that as food prices increase due to strains on natural resources, people's motivation to decrease their food waste rises. However, food wastes in households and retail are highest in the industrialized world - exactly where people can afford such wastage. What this scenario study shows is that it is possible to feed a growing world population a balanced and adequate diet, i.e. a diet with a lot less meat than the current average diet in the developed world, while respecting the limitations our natural resources pose. It is, however, unlikely that people will be willing to give up meat consumption on a large scale.

This study also points out opportunities in our agricultural system. From a supply-side perspective it can be concluded that technological development is of vital importance. Yield increases reduce land requirements and technological development can improve the efficiencies of irrigation and fertilization. The potential for growth in the developing countries is large, and also quite necessary in view of the population increases that are to be expected. The current low yields in many developing countries reflect the potential for development. Such development is not something which will happen naturally; it will take long-term dedication of such stakeholders as governments, industry, development agencies and of course farmers. Furthermore, the Low-Input World/B2 scenario has shown that it is absolutely necessary to increase yields, while the Affluent World/A1 scenario shows that even maximizing yields and feeding efficiencies is not enough if a 'Western' diet is adopted on a global scale. These results give a clear message to decision makers on all levels of society - government, companies, retail and households. Because the current diet in the industrialized world cannot be sustained on a global scale, people in the industrialized world will have to change their lifestyles if they want to have a more equitable world, or accept the fact that their food choices have large-scale consequences. This may be a tenable situation for individuals, as long as they can afford what they consume, however, governments will have to make far-reaching decisions if they are serious about reaching global equity and eliminating undernutrition.

\section{Acknowledgements}

This research comprises Ingrid Y.R. Odegard's master's thesis research for the Master of Science program in Industrial Ecology at Leiden University and Delft University of Technology. The Center for Industrial Ecology at Yale University is gratefully acknowledged for waiving the tuition fee and letting Ingrid Odegard attend as a Visiting Assistant in Research to do literature research. The authors want to thank Harry Croezen and an anonymous reviewer for giving valuable comments on the text. 


\section{Appendix A. Supplementary data}

Supplementary data to this article can be found online at http://dx. doi.org/10.1016/j.ecolecon.2013.10.005.

\section{References}

Alexandratos, N., Bruinsma, J., Bödeker, G., Schmidhuber, J., Broca, S., Shetty, P., Grazia Ottaviani, M., 2006. World agriculture: towards 2030/2050, prospects for food, nutrition, agriculture and major commodity groups. Interim Report, Global Perspective Studies Unit.Food and Agriculture Organization of the United Nations, Rome (June).

Bruinsma, J. (Ed.), 2003. World Agriculture: Towards 2015/2030, An FAO Perspective. FAO, Earthscan publications Ltd.

Bruinsma, J., 2009. The resource outlook to 2050: by how much do land water and crop yields need to increase by 2050? Paper Presented at the FAO Expert Meeting, 2426 June 2009, Rome on "How to Feed the World in 2050".

Cordell, D., Drangert, J., White, S., 2009. The story of phosphorus: global food security and food for thought. Glob. Environ. Chang. 19, 292-305.

De Fraiture, C., Wichelns, D., 2010. Satisfying future water demand for agriculture. Agric Water Manag. 97, 502-511.

De Fraiture, et al., 2007. Looking Ahead to 2050: Scenarios of Alternative Investment Approaches. IWMI.

EcoSanRes, 2008. Stockholm environmental institute, closing the loop on phosphorus EcoSanRes Factsheet, 4 (May).

Ewert, F., Rounsevell, M.D.A., Reginster, I., Metzger, M.J., Leemans, R., 2005. Future scenarios of European agricultural land use, I. Estimating changes in crop productivity. Agric. Ecosyst. Environ. 107, 101-116.

FAO and IFA, Food and Agriculture Organization of the United Nations and International Fertilizer Industry Association, 2000. Fertilizers and Their Use, a Pocket Guide for Extension Officers, fourth edition. (Rome).

FAO, Food and Agriculture Organization of the United Nations, Fertilizer and Plant Nutrition Service, Land and Water Development Division, 1984. Fertilizer and plant nutrition guide. FAO Fertilizer and Plant Nutrition Bulletin, 9 (Rome).

FAO, Food and Agriculture Organization of the United Nations, 2006. Plant nutrition for food security; a guide for integrated nutrient management. FAO Fertilizer and Plant Nutrition Bulletin, 16 (Rome).

FAO, Food and Agriculture Organization of the United Nations, 2009. How to feed the World in 2050. http://www.fao.org/fileadmin/templates/wsfs/docs/expert_paper/ How_to_Feed_the_World_in_2050.pdf.

FAOSTAT, FAO, 2011. Time-series and cross sectional data relating to food and agriculture last updated: 2011, accessed: 2010-2011 http://www.faostat.fao.org.

Fischer, G., Van Velthuizen, H., Medow, S., Nachtergaele, F., at IIASA, International Institute for Applied Systems Analysis, and FAO, Food and Agriculture Organization of the United Nations, Global Agro-ecological Assessment for Agriculture in the 21st Century CD-ROM, 2002, available at http://www.iiasa.ac.at/Research/LUC/SAEZ/ accessed November 2010.

Foley, J.A., DeFries, R., Asner, G.P., Barford, C., Bonan, G., Carpenter, S.R., Chapin, F.S., Coe M.T., Daily, G.C., Gibbs, H.K., Helkowski, J.H., Holloway, T., Howard, E.A., Kucharik, C.J., Monfreda, C., Patz, J.A., Prentice, I.C., Ramankutty, N., Snyder, P.K., 2005. Global consequences of land use. Science 309 (July).

Galli, A., Wiedmann, T., Ercin, E., Knoblauch, D., Ewing, B., Giljum, S., 2012. Integrating ecological, carbon and water footprint into a "footprint family" of indicators: definition and role in tracking human pressure on the planet. Ecol. Indic. 16, 100-112.

Galloway, J.N., Burke, M., Bradford, G.E., Naylor, R., Falcon, W., Chapagain, A.K., Gaskell, J.C., McCullough, E., Mooney, H.A., Oleson, K.L.L., Steinfeld, H., Wassenaar, T., Smil, V., 2007. International trade in meat: the tip of the pork chop. Ambio 36 (8) (December).

Gerbens-Leenes, W., Nonhebel, S., 2005. Food and land use. The influence of consumption patterns on the use of agricultural resources. Appetite 45, 24-31.

Grigg, D., 1995. The pattern of world protein consumption. Geoforum 26 (1), 1-17.

Hoekstra, A.Y., 2009. Human appropriation of natural capital: a comparison of ecological footprint and water footprint analysis. Ecol. Econ. 68, 1963-1974.

Hoekstra, A.Y., Chapagain, A.K., 2008. Globalization of Water: Sharing the Planet's Freshwater Resources. Wiley-Blackwell, Oxford, UK.

Hoekstra, A.Y., Mekonnen, M.M., 2012. The water footprint of humanity. PNAS 109 (9), 3232-3237 (February 28).

IFA, International Fertilizer Industry Association, 1992. World Fertilizer Use Manual. http://www.fertilizer.org/ifa/HomePage/LIBRARY/Our-selection2/World-FertilizerUse-Manual/by-type-of-crops.

Nakicenovik, N., Alcamo, J., Davis, G., de Vries, B., Fenman, J., et al., 2000. Special Report on Emission Scenarios: A Special Report of Working Group III of the Intergovernmental Panel on Climate Change. Cambridge University Press, Cambridge (available at: http://www.ipcc.ch/ipccreports/sres/emission/index.php?idp=87).

Kantor, L.S., Lipton, K., Manchester, A., Oliveira, V., 1997. Estimating and addressing America's food losses. FoodReview 2-12 (January-April).

Keyzer, M.A., Merbis, M.D., Pavel, I.F.P.W., Wesenbeeck, C.F.A., 2005. Diet shifts towards meat and the effects on cereal use: can we feed the animals in 2030? Ecol. Econ. 55, 187-202.
Leach, A.M., Galloway, J.N., Bleeker, A., Erisman, J.W., Kohn, R., Kitzes, J., 2012. A nitrogen footprint model to help consumers understand their role in nitrogen losses to the environment. Environ. Dev. 1, 40-66.

Liu, J., Savenije, H.H.G., 2008. Food consumption patterns and their effect on water requirement in China. Hydrol. Earth Syst. Sci. 12, 887-898.

Lotze-Campen, H., Müller, C., Bondeau, A., Smith, P., Lucht, W., 2006. Rising food demand, climate change and the use of land and water. In: Brouwer, F., McCarl, B.A. (Eds.), Agriculture and Climate Beyond 2015. Springer, The Netherlands, pp. 109-129.

Lutz, W., Sanderson, W., Scherbov, S., 2008. IIASA's 2007 probabilistic world population projections. IIASA World Population Program Online Database of Results. (accessed October 2009, available at: http://www.iiasa.ac.at/Research/POP/proj07/index.html? $\mathrm{sb}=5$, http://www.iiasa.ac.at/Research/POP/proj07/ptotr_all.xls).

Odegard, I.Y.R., 2011. The Future of Food, Scenarios and the Effects on Resource Use in Agriculture. (MSc Thesis) Institute of Environmental Sciences, Leiden University (June).

OECD, 2010. Health at a Glance: Europe 2010. OECD Publishing (accessed May 2011, available at http://www.oecd-ilibrary.org/social-issues-migration-health/health-ata-glance-europe-2010_health_glance-2010-en).

Roberts, T.L., 2008. Global Potassium Reserves and Potassium Fertilizer Use, presentation of president of International Plant Nutrition Institute at Global Nutrient Cycling Symposium, Oktober.

Rosegrant, M.W., Paisner, M.S., Meijer, S., Witcover, J., 2001a. Global Food Projections to 2020, Emerging Trends and Alternative Futures. International Food Policy Research Institute, Washington, D.C.(August).

Rosegrant, M.W., Paisner, M.S., Meijer, S., Witcover, J., 2001b. Global food outlook, trends, alternatives and choices. A 2020 Vision for Food, Agriculture, and the Environment Initiative.International Food Policy Research Institute, Washington, D.C.(August).

Sattari, S.Z., Bouwman, A.F., Giller, K.E., Ittersum, M.K., 2012. Residual soil phosphorus as the missing piece in the global phosphorus crisis puzzle. PNAS 109 (16) (April 17)

Smil, V., 2001. Feeding the World; a Challenge for the Twenty-First Century. The MIT Press, Cambridge, USA.

Steen, I., 1998. Phosphorus availability in the 21st century; management of a nonrenewable resource. Phosphorus Potassium 217, 25-31.

Tilman, D., Fargione, J., Wolff, B., D'Antiono, C., Dobson, A., Howarth, R., Schindler, D., Schlesinger, W.H., Simberloff, D., Swackhamer, D., 2001. Forecasting agriculturally driven global environmental change. Science 292 (April).

Tuomisto, H.L., Roy, A.G., 2012. Could cultured meat reduce environmental impact of agriculture in Europe? 8th International Conference on LCA in the Agri-Food Sector, Rennes, France, 2-4 October 2012.

UN, Department of Economic and Social Affairs, Population Division, 2011. World Population Prospects: The 2010 Revision (April).

UN, United Nations, 2010. The Millennium Development Goals Report 2010 (New York).

UN, United Nations, UN Population Division, retrieved October 2009, from World Population Prospects: The 2008 Revision Population Database: http://esa.un.org/unpp, 2009.

USGS, U.S. Geological Survey, 2009. Mineral Commodity Summaries 2009

Van ham, D., Mekonnen, M.M., Hoekstra, A.Y., 2013. The water footprint of the EU for different diets. Ecol. Indic. 32, 1-8.

Van Huis, A., Van Itterbeeck, J., Klunder, H., Mertens, E., Halloran, A., Muir, G., Vantomme, P., 2013. Edible insects: future prospects for food and feed security. Forestry Paper, 171. FAO (Food and Agriculture Organization of the United Nations), Rome.

Van Vliet, J., 2010. PBL, SRES PPP data, Personal Communication.

Vinnari, M., Tapio, P., 2009. Future images of meat consumption in 2030. Futures 41, 269-278.

Vitousek, P.M., Mooney, H.A., Lubchenco, J., Melillo, J.M., 1997. Human domination of earth's ecosystems. Science 277, 494.

Wackernagel, M., Schulz, N.B., Deumling, D., Callejas Linares, A., Jenkins, M., Kapos, V., Monfreda, C., Loh, J., Myers, N., Norgaard, R., Randers, J., 2002. Tracking the overshoot of the human economy. PNAS 99 (14), 9266-9271 (July 9).

Wirsenius, S., 2000. Human use of land and organic materials. Modeling the Turnover of Biomass in the Global Food System.Department of Physical Resource, Theory, Chalmers University of Technology and Göteborg University, Göteborg, Sweden.

Wirsenius, S., Azar, C., Berndes, G., 2010. How much land is needed for global food production under scenarios of dietary changes and livestock productivity increases in 2030 ? Agric. Syst. 103, 621-638

WWF, 2012. Living Planet Report 2012, Biodiversity, Biocapacity and Better Choices. In: Grooten, Monique (Ed.), WWF in corporation with the Zoological Society of London and the Global Footprint Network.

\section{Databases}

AQUASTAT, FAO/NRL, 2011. FAO's Information System on Water and Agriculture. last updated 2011, accessed 2010-2011 http://www.fao.org/nr/water/aquastat/main/index. stm.

FERTISTAT, 2007. Food and agriculture organization of the United Nations, plant production and protection division, fertilizer use statistics. updated 2007, accessed: February 2011 http://www.fao.org/ag/agl/fertistat/index_en.htm. 